\title{
Developing a standardized tool for assessing the ICT competence of the agricultural extension personnel
}

\author{
Deepti Kothari* \\ Department of Agricultural Communication, College of Agriculture, G.B Pant University of \\ Agriculture and Technology, Pantnagar, US Nagar-263145 (Uttarakhand), India. \\ V.L.V. Kameswari \\ Department of Agricultural Communication, College of Agriculture, G.B Pant University of \\ Agriculture and Technology, Pantnagar, US Nagar-263145 (Uttarakhand), India \\ *Corresponding author. E-mail: deeptikothari15@gmail.com
}

\begin{abstract}
Knowledge and information is the key ingredient for driving the engine socio-economic progress of an economy in the present century. Therefore, development in $21^{\text {st }}$ century is driven by the use of Information and Communication Technologies (ICTs) for collection, storage, processing, retrieval and dissemination of the agriculture information to farmers. ICTs offer means of facilitating two-way interaction in an easy, fast and reliable way between research-extension-farmer systems. In order to reap the potential benefits of ICTs in agriculture, development functionaries must be well competent in using all means of information and communications technologies for extension. Extension personnel's competence in using ICTs for agriculture and allied activities benefit's the individual, organizations and nation. Accordingly, the thrust of training for extensionists' should be aligned towards designing competency-based ICT trainings. The preliminary step for planning a competency-based ICT training programme is assessment of the training gap i.e. difference between existing and required ICT competencies of extension personnel. Studies done earlier in this context are very diverse and focus on specific ICTs, rather than whole. This paper presents a set of standardized 45 statements for measuring the ICT competence of the extension personnel. A total of 118 statements were sent to 154 experts for relevancy testing through online Google form. The data obtained was analyzed using SPSS software and MS Excel. With the use of outlier analysis, factor analysis and reliability analysis, ICT competence tool for extension personnel were finalized. The competency tool will contribute towards effective human resource development interventions for the extension personnel.
\end{abstract}

Keywords: Competence, Information and Communication Technologies, Factor analysis

\section{Article Info}

DOI:10.31018/jans.v11i2.2059

Received: April 8, 2019

Revised: May 6, 2019

Accepted: May 11, 2019

\section{How to Cite}

Kothari, D. and Kameswari, V.L.V. (2019).Developing a standardized tool for assessing the ICT competence of the extension personnel in context of agricultural extension. Journal of Applied and Natural Science, 11(2):352-360 https://doi.org/10.31018/ jans.v11i2.2059

\section{INTRODUCTION}

Development of an economy is determined by its resource-use efficiency. Management of resources directly influences the state of social, economic, technological and political forces of production. In context of developing economies like India, management of agriculture resources is a central concern. As due to diversity of agro-ecological settings, produces, needs, opportunities and prospects the challenges faced by agriculture-based economies are innumerable. The water-scarce rain fed areas, which accounts for 63 per cent of the cultivated land, exhibit low and also unstable yield and technology transfer gaps are much wider as compared to those in un-irrigated areas (Chatterjee and Prabhakar, 2009). Sustaining growth rate and achieving the required food grain production requirement seems to be a herculean task considering challenges like non-expanding land, depleting soil and water resources, adverse impact of climate change (Lele et al., 2010), rising cost of production, diminishing agriculture labor availability and reduced interest of farmers in agriculture (NSAE, 2009). The growing population, changes in demand and consumption patterns (Lele et al., 2010), rise in fragmented land holdings, decrease in soil fertility due to excessive use of chemical fertilizers, rising poverty, economic stagnation, worsening environmental degradation further adds severity to this issue. Thus, agricultural extension in the country needs to be strengthened, as it is the key for to reducing the yield gap in farmer fields and increasing agricultural growth (Glendenning et al., 2010). Access to information and improved communica- 
tion networks is a crucial requirement for sustainable agriculture development. Omotayo (2005) stated that agricultural extension to a large extent depends on exchange of latest and up-to-date agricultural information between and among farmers and a broad range of other actors. ICTs as an extension tool will enhance flow of information in the application of agricultural extension services. The term ICTs refers to a family of technologies used to process, store and disseminate information, facilitating the performance of informationrelated human activities, provided by, and serving both the public at-large as well as the institutional and business sectors (Salomon et al., 1999). It encompasses all equipment and tools (inclusive of traditional technologies of radio, video, and television to the newer technologies of computers, hardware, firmware, etc.), as well as the methods, practices, processes, procedures, concepts, and principles that comes into play during information and communication activities (Federal Ministry of Education, Nigeria, 2010).

ICTs have a potential to go beyond the boundaries of space and time, for accessing Information, training and education, while also facilitating processing of information by the user at the same time. Molina et al. (2016) explicitly stated ICTs have some traits as i) storage and transmission of large volumes information; ii) dynamism and formalism to present changing information in a cohesively structured and logical way; iii) hypermedia and multimedia to represent information in various formats in a non-linear way; iv) interactivity to facilitate manipulation of information in two directions; and v) connectivity for networking and the new possibilities for group and collaborative working that provide many ways of improving quality. Coll (2004) stated that ICTs in agricultural extension and rural development have witnessed an upsurge in almost all areas of rural life in several developing countries of the world. CTA (2003) clearly mention that ICTs in context of developing economies is serving as a medium for adequate access to agricultural information, despite the persisting problems of access, connectivity, literacy, content and costs. The diffusion of ICTs in the agricultural sector provides opportunities for increasing productivity, income generation, decreasing regional disparity and improving market linkages (Ratna, 2008). ICTs can serve to equip the communities with very crucial scientific knowledge and information can greatly impact agricultural production and food security.

In most of the developing economies agricultural information is disseminated amongst farming communities by public extension workers. The plight associated with this primitive structure of information dissemination is that, being bureaucratic they lack in terms of reach, providing up-todate and tailored information to the farmers (Bell,
2015). Furthermore, the wide farmer extension ratio i.e., 1:2879 also limits the reach and access of extension services (Mukherjee and Maity, 2015). Hence, innovative information systems are vital for addressing this gap (Munyua, 2008). The extension approach needs to be more diversified, knowledge-intensive, demand driven, effective and resource efficient. Simultaneously, the role extension functionaries should be evolved as facilitators of information, knowledge, communication, advocacy services and broader services for improving livelihoods. Introduction of ICTs in extension framework can meet these expectations really well. Extension personnel's knowledge and skills to manipulate ICTs tools is essential requirement for effective and successful extension service delivery (Lawal Adebowale, 2009; Albert, 2014).

Thus, becoming proficient in using ICTs to fulfill job functions by the extension personnel has become the need of the hour. The ICT literacy as stated by 'The Minnesota Governor's Council on Developmental Disabilities' focuses on the developing abilities in an individual in order to: i) Use technology as a tool to research, organize, evaluate, and communicate information, ii) Use digital technologies (computers, PDAs, media players, GPS, etc), communication/networking tools and social networks appropriately to access, manage, integrate, evaluate and create information to successfully function in a knowledge economy and iii) Apply a fundamental understanding of the ethical/ legal issues surrounding the access and use of information technologies. ICT literacy further extends to the concept of ICT competence which calls for deepening of ICT related concepts gained through education and experience. Information and communication technology competence is based on sets of relevant understandings, knowledge, attitudes and skills. Kirschner and Woperies (2003) highlighted some major ICT competencies as: i) Making personal use of ICTs, ii) Mastery of a range of educational paradigms that make use of ICTs, iii) Making use of ICTs as minds tools, iv) Using ICTs as tool for teaching, v) Mastering a range of assessment paradigms which involves use of ICTs and vi) Understanding the policy dimensions of the use of ICTs for teaching and learning. Competence in using ICTs is related with tasks of information access and management, problem solving, decision making, communicating, creative expression, and empirical reasoning.

The importance of information and communication technologies for development functionaries is inevitable. Nowadays, both extension service providers and extension clients are experimenting with new digital opportunities to exchange, process, manage and communicate information for helping rural farmers effectively utilize any agricul- 
tural information received (Sanusi et al., 2010). Individual characteristics, information needs and attitudes of extension workers on ICT have the impact on searching and acquiring information from relevant information sources and deliver them to their clientele through appropriate ICT (Koyenikan, 2011). Therefore, equally important is to understand the needs of extension personnel for systematic improvement of knowledge and skills of using ICTs. Mishra (1990) reported that training needs for extension personnel can be defined in terms of gap between job requirement and job performance. For training of extension personnel, the needs assessment should be based on needs, wants and aspirations of the extension workers themselves since they can easily identify their own plus and minus points. The national priorities, developmental programmes, farmers' felt needs for training, individual and institutional priorities also lay the foundation within the ambit of which the training priorities of extension personnel are set.

The primary objective of the study was designing and validating standardized tool for assessing the training needs of the extension personnel associated with use of ICTs for agricultural extension.

\section{MATERIALS AND METHODS}

Participants and procedure: The study was conducted in the year 2018, and the process of developing (included searching, manipulating and finalizing) set of statements, sending questionnaire, analyzing data and interpreting results took a period of about 7 to 8 months. The respondents for the survey were the people belonging to the field of extension and related activities i.e., research scholars, academicians and professionals. The sample of respondents for the survey was not restricted to any specific region of the country.

Research instrument: For collection of data, an online questionnaire was created using Google form and was sent to the above mentioned categories of respondents. The e-mail addresses of the respondents were collected from the carbon copy link of the mails forwarded to the researcher by different conference/seminar organizers. A total of 154 e-mail addresses were screened and were forwarded a copy of Google form-based questionnaire. The online questionnaire comprised of two broad sections-

Section 1 comprised of the covering letter

Section 2 consisted of the basic information of the respondent and the statements related to ICT competencies

Each of the statement was supposed to be judged by the respondents in terms of being suitable for measuring ICT-use competency of the extension personnel. A total of 118 statements were relating to ICT-use competencies were mentioned in the online questionnaire. The statements were selected on the basis of available research paper, articles, books and other literature as well as the personnel experience of the researcher. Every care was taken that competency in context of all ICTs relating to agricultural extension, either conventional or modern were included in the questionnaire. For each of the competencies, the respondents were expected to select any one option from "Not Relevant, Relevant and Very Relevant". Besides this, an option was also made available for comment (in terms of correction, clarification and improvement in the syntax of the statements) on each of the competency statements. The form sent for reminder twice within a gap of 10-15 days, to those respondents from where responses were not obtained after first email and even second e-mail. Overall after a period of about two months, out of 154 only 57 respondents submitted their online responses.

Data analysis: The obtained responses were retrieved in the form of excel sheet, which is one of the in-built features of the Google form. The analysis of the obtained data was done following 5 basic steps as:

- Checking the obtained data table (corrections, left responses, comments, etc.)

- Outlier analysis using quartile method

- Feeding the data in SPSS version 20 software

- Conducting Factor Analysis

- Assessing the reliability and validity of statements and finalization of competency tool

\section{RESULTS}

Characteristics of the respondents: A perusal of Table 1 stated that most of the respondents were research scholars $(61.41 \%)$, followed by teaching professionals $(21.50 \%)$ and scientists $(17.54 \%)$, in terms of designation held by them presently. Table 1 reveled that most of the respondents belonged from central and deemed institutions $(43.86 \%)$, followed closely by belonging to SAUs (33.33\%) and research institutions $(22.81 \%)$. It is also clearly visible form Table 1 that majority of the respondents who submitted their responses were from agricultural sciences $(66.67 \%)$ followed by allied sciences (33.33\%).

Outlier analysis using quartile method: Outlier analysis is one of the most important procedures that should be used by the researcher on the data set obtained from the experiment, prior initiating with the process of data analysis. Outlier is defined as, 'an observation (or subset of observations) which appears to be inconsistent with the remainder of that set of data' (Barnett and Lewis, 1994). An outlying observations, tends to deviate from all other members of the sample remarkably (Grubbs, 1969). The occurrence of outliers in any distribu- 
Table 1. Profile characteristics of the respondents.

\begin{tabular}{cll}
\hline S. N. & Designation & Frequency (N=57) \\
\hline 1. & Teaching professionals (Professor, Associate/Assistant Professor, Lecturer, etc.) & $12(21.05)$ \\
2. & Scientists (Directors, SMS, etc.) & $10(17.54)$ \\
3. & Research Scholars (Ph.D.Students, PDF, RA, etc.) & $35(61.41)$ \\
S. N. & Organization & Frequency \\
1. & State Agricultural Universities (SAUs) & $19(33.33)$ \\
2. & Central and Deemed Universities & $25(43.86)$ \\
3. & Research institutes & $13(22.81)$ \\
S. N. & Department & Frequency \\
1. & Agricultural sciences & $38(66.67)$ \\
2. & Allied sciences (agriculture) & $19(33.33)$ \\
\hline
\end{tabular}

$\mathrm{N}=$ Total number of respondents, Figure in the parenthesis indicates percentages

Table 2. Outlier analysis with use of Quartile method.

\begin{tabular}{|c|c|c|c|c|c|c|}
\hline $\begin{array}{l}\text { S. } \\
\text { N. }\end{array}$ & $\begin{array}{l}\text { Total Score of } \\
\text { ICT-use competencies }\end{array}$ & Outlier & Calculated values & $\begin{array}{l}\text { S. } \\
\text { N. }\end{array}$ & $\begin{array}{l}\text { Total Score of ICT- } \\
\text { use competencies }\end{array}$ & Outlier \\
\hline 1. & 232 & FALSE & & 30. & 234 & FALSE \\
\hline 2. & 317 & FALSE & & 31. & 328 & FALSE \\
\hline 3. & 294 & FALSE & & 32. & 240 & FALSE \\
\hline 4. & 237 & FALSE & & 33. & 216 & FALSE \\
\hline 5. & 288 & FALSE & & 34. & 261 & FALSE \\
\hline 6. & 266 & FALSE & & 35. & 274 & FALSE \\
\hline 7. & 209 & FALSE & & 36. & 242 & FALSE \\
\hline 8. & 241 & FALSE & & 37. & 327 & FALSE \\
\hline 9. & 265 & FALSE & & 38. & 303 & FALSE \\
\hline 10. & 257 & FALSE & & 39. & 309 & FALSE \\
\hline 11. & 286 & FALSE & & 40. & 280 & FALSE \\
\hline 12. & 313 & FALSE & & 41. & 305 & FALSE \\
\hline 13. & 253 & FALSE & $q 1=237$ & 42. & 244 & FALSE \\
\hline 14. & 261 & FALSE & $q 3=283$ & 43. & 212 & FALSE \\
\hline 15. & 266 & FALSE & $\mathrm{IQR}=46$ & 44. & 270 & FALSE \\
\hline 16. & 252 & FALSE & Upper Bound $=352$ & 45. & 251 & FALSE \\
\hline 17. & 228 & FALSE & Lower Bound= 168 & 46. & 48 & TRUE \\
\hline 18. & 265 & FALSE & & 47. & 261 & FALSE \\
\hline 19. & 123 & TRUE & & 48. & 260 & FALSE \\
\hline 20. & 307 & FALSE & & 49. & 283 & FALSE \\
\hline 21. & 286 & FALSE & & 50. & 202 & FALSE \\
\hline 22. & 283 & FALSE & & 51. & 246 & FALSE \\
\hline 23. & 234 & FALSE & & 52. & 276 & FALSE \\
\hline 24. & 281 & FALSE & & 53. & 259 & FALSE \\
\hline 25. & 257 & FALSE & & 54. & 225 & FALSE \\
\hline 26. & 236 & FALSE & & 55. & 283 & FALSE \\
\hline 27. & 230 & FALSE & & 56. & 232 & FALSE \\
\hline 28. & 248 & FALSE & & 57. & 256 & FALSE \\
\hline 29. & 297 & FALSE & & & & \\
\hline
\end{tabular}

S. N. 19 and 48 were found to be outliers in the study

tion although is a matter of chance. Outliers are present in any data set either due to variability of data set, experimental error, faulty recordings, execution and measurement issues (Huang et al., 2006) or due to inclusion of a population that has a heavy-tailed distribution. Outlier points can therefore indicate faulty data, erroneous procedures, or areas where a certain theory might not be valid. However, as the number of sample increases the number of outlier tends to reduce. Outliers are the most extreme observations and include the sample maximum as well as sample minimum observations. In order to analyze outli- ers, there are some commonly used methods like scatter diagram, histogram, box plot, quartile method, etc. In the present research study, Quartile method has been used for analysis of outlier. For applying this method firstly total score of all individuals for 118 statements was done in MS excel sheet. Then q1 (first quartile), q2 (second quartile/median/inter-quartile range) and q3 (third quartile) was calculated using the formula function. With the help of $q 1$ and $q 2$, the value of upper bound score $\left\{q 3+\left(1.5^{*} q 2\right)\right\}$ and lower bound score $\left\{q 1-\left(1.5^{*} q 2\right)\right\}$ was calculated. Then using the logical function equation in excel $[\{=O R$ 
Table 3. Final draft of standardized tool for assessing ICT-use competencies.

\begin{tabular}{|c|c|c|c|}
\hline S. $\mathbf{N}$. & Variable & ICT-use competency & $\begin{array}{l}\text { Correlation } \\
\text { Value }\end{array}$ \\
\hline 1. & Var76 & Making graphs using MS Excel & 0.874 \\
\hline 2. & Var73 & Tabulation of collected data using MS Excel & 0.792 \\
\hline 3. & Var116 & Sharing links of websites via whatsapp & 0.777 \\
\hline 4. & Var77 & Use of MS Word for making field reports & 0.768 \\
\hline 5. & Var74 & Performing simple statistical analysis of data using MS Excel & 0.733 \\
\hline 6. & Var101 & Using online money transfer apps like BHIM, PayU, Paytm etc. & 0.645 \\
\hline 7. & Var113 & Sending attachments using Whatsapp & 0.611 \\
\hline 8. & Var85 & Sending large data using compressor software (ZIP, RAR, etc.) & 0.629 \\
\hline 9. & Var43 & Creating an agricultural blog & 0.881 \\
\hline 10. & Var44 & Micro-blogqing of agricultural Research and Development & 0.835 \\
\hline 11. & Var42 & Creation of e-newsletter & 0.805 \\
\hline 12. & Var80 & Inserting front page in the word document & 0.901 \\
\hline 13. & Var81 & Designing report on MS Publisher format & 0.790 \\
\hline 14. & Var72 & Scanning of documents using computer scanner & 0.780 \\
\hline 15. & Var89 & $\begin{array}{l}\text { Use of software for cloud storage, file synchronization, personal cloud and } \\
\text { client software (Dropbox, Google drive, }\end{array}$ & 0.803 \\
\hline 16. & Var40 & Access to free software meant for specialized extension delivery & 0.797 \\
\hline 17. & Var92 & Sending e-mails to one individual & 0.856 \\
\hline 18. & Var93 & Sending e-mails to multiple recipients & 0.783 \\
\hline 19. & Var94 & Sending e-mail with attachments of documents & 0.739 \\
\hline 20. & Var107 & Video conferencing using applications of smart phone & 0.633 \\
\hline 21. & Var108 & Using web cameras for video conferencing & 0.614 \\
\hline 22. & Var102 & $\begin{array}{l}\text { Enabling security system in the computer and mobile set by PIN/ } \\
\text { Password/ Thumb scanning }\end{array}$ & 0.828 \\
\hline 23. & Var104 & $\begin{array}{l}\text { Installing internet security suite (Kespersky, Guardian, Quick Heal, etc.) } \\
\text { for protection against web threats, malwares etc. in the computer }\end{array}$ & 0.663 \\
\hline 24. & Var60 & Use of presentation making software like Prezi & 0.770 \\
\hline 25. & Var6 & Subscribing/ reading online publications on agriculture & 0.863 \\
\hline 26. & Var2 & $\begin{array}{l}\text { Using a search engine (Google Chrome, Mozilla, Internet explorer, etc.) to } \\
\text { locate information }\end{array}$ & 0.667 \\
\hline 227. & Var14 & Downloading media (audio and video) files on agriculture from internet & 0.640 \\
\hline 28. & Var71 & Making database using MS Access & 0.660 \\
\hline 29. & Var54 & Describe use of computer in agriculture extension to others & 0.848 \\
\hline 30. & Var49 & Identification of computer hardware and its functions & 0.863 \\
\hline 31. & Var50 & Identification of computer software and its functions & 0.845 \\
\hline 32. & Var12 & Handling and installing software package & 0.833 \\
\hline 33. & Var112 & Creation of whatsapp group of the scientists and farmers & 0.697 \\
\hline 34. & Var58 & Working with different Operating systems (Windows, Linux) & 0.846 \\
\hline 35. & Var67 & Handling and displaying content using LCD projector & 0.605 \\
\hline 36. & Var4 & Navigating pages on the internet & 0.759 \\
\hline 37. & Var1 & Finding information in the Internet address book & 0.881 \\
\hline 38. & Var45 & $\begin{array}{l}\text { Designing of instructional material with a combination of handouts, power- } \\
\text { point, videos etc. }\end{array}$ & 0.831 \\
\hline 39. & Var9 & Using favourites (bookmarks) for quick viewing & 0.686 \\
\hline 40. & Var15 & Listening to online radio on agricultural programme & 0.826 \\
\hline 41. & Var95 & Communicating with discussion newsgroup (e.g. Google/Yahoo! Groups) & 0.842 \\
\hline 42. & Var59 & Preparing powerpoint with animation/transition and other effects & 0.817 \\
\hline 43. & Var118 & Designing an organizational Management Information System & 0.948 \\
\hline 44. & Var33 & Burning the designed content into a CD/DVD & 0.861 \\
\hline 45. & Var3 & Finding recently viewed pages & 0.847 \\
\hline
\end{tabular}

( $x>$ upper bound, $x<$ lower bound)\}] results were obtained in the form of TRUE/FALSE. The observations for whom result was found to be true were the outliers. Outliers were those observations whose value was more than the upper bound and less than the lower bound. An analysis of Table 2 , stated that amongst a total of 57 respondents, who submitted their responses only two respondents i.e., respondent no. 19 and 46 were found to be the outliers (Table 2).

Feed the data into the SPSS data sheet: The observations obtained from outliers were thus eliminated from the excel sheet, for applying further statistics. SPSS is one of the common statistical software packages used for simple to complex data analysis. The data in SPSS is feed by just copying the data set obtained in the excel sheet. SPSS interface has two view i) Data view where 
Table 4. Reliability statistics.

\begin{tabular}{|c|c|c|c|c|c|}
\hline \multirow{2}{*}{\multicolumn{2}{|c|}{$\begin{array}{c}\text { Cronbach's Alpha } \\
0.920\end{array}$}} & \multicolumn{3}{|c|}{ Cronbach's Alpha Based on Standardized Items } & \multirow{2}{*}{\begin{tabular}{|c|} 
Number of Items \\
45
\end{tabular}} \\
\hline & & \multicolumn{3}{|c|}{0.920} & \\
\hline \multicolumn{6}{|c|}{ Table 5. Item-total statistics. } \\
\hline & $\begin{array}{l}\text { Scale Mean if } \\
\text { Item Deleted }\end{array}$ & $\begin{array}{l}\text { Scale Variance if } \\
\text { Item Deleted }\end{array}$ & $\begin{array}{l}\text { Corrected Item- } \\
\text { Total Correlation }\end{array}$ & $\begin{array}{l}\text { Squared Multiple } \\
\text { Correlation }\end{array}$ & $\begin{array}{l}\text { Cronbach's Alpha if } \\
\text { Item Deleted }\end{array}$ \\
\hline Var1 & 98.2037 & 178.543 & 0.358 & & 0.919 \\
\hline Var2 & 97.9444 & 178.846 & 0.347 & . & 0.919 \\
\hline Var3 & 98.3333 & 183.887 & -0.007 & . & 0.923 \\
\hline Var4 & 98.2778 & 181.563 & 0.127 & . & 0.921 \\
\hline Var6 & 98.0556 & 180.997 & 0.157 & . & 0.921 \\
\hline Var9 & 98.1296 & 182.983 & 0.045 & . & 0.922 \\
\hline Var12 & 98.2963 & 179.156 & 0.236 & . & 0.921 \\
\hline Var14 & 97.9815 & 176.245 & 0.426 & . & 0.919 \\
\hline Var15 & 98.3333 & 179.585 & 0.212 & . & 0.921 \\
\hline Var33 & 98.4630 & 178.027 & 0.352 & . & 0.919 \\
\hline Var40 & 98.1852 & 174.003 & 0.561 & . & 0.917 \\
\hline Var42 & 98.1481 & 174.695 & 0.560 & . & 0.917 \\
\hline Var43 & 98.0741 & 174.183 & 0.596 & . & 0.917 \\
\hline Var44 & 98.1296 & 174.417 & 0.570 & . & 0.917 \\
\hline Var45 & 98.0000 & 173.396 & 0.626 & . & 0.917 \\
\hline Var49 & 98.3704 & 177.973 & 0.363 & . & 0.919 \\
\hline Var50 & 98.2778 & 178.808 & 0.350 & . & 0.919 \\
\hline Var54 & 98.0000 & 179.208 & 0.270 & . & 0.920 \\
\hline Var58 & 98.2963 & 176.590 & 0.391 & . & 0.919 \\
\hline Var59 & 98.1111 & 176.553 & 0.431 & . & 0.919 \\
\hline Var60 & 98.5741 & 177.910 & 0.376 & . & 0.919 \\
\hline Var67 & 98.1296 & 176.417 & 0.501 & . & 0.918 \\
\hline Var71 & 98.3148 & 176.899 & 0.449 & . & 0.918 \\
\hline Var72 & 98.2778 & 174.129 & 0.500 & . & 0.918 \\
\hline Var73 & 98.0000 & 172.755 & 0.634 & . & 0.916 \\
\hline Var74 & 97.9815 & 171.830 & 0.721 & . & 0.916 \\
\hline Var76 & 98.0185 & 171.188 & 0.700 & . & 0.916 \\
\hline Var77 & 98.0370 & 174.678 & 0.554 & . & 0.917 \\
\hline Var80 & 98.2407 & 174.526 & 0.465 & . & 0.918 \\
\hline Var81 & 98.2593 & 174.158 & 0.512 & . & 0.918 \\
\hline Var85 & 98.1852 & 175.210 & 0.515 & . & 0.918 \\
\hline Var89 & 98.1667 & 174.255 & 0.596 & . & 0.917 \\
\hline Var92 & 98.2037 & 177.788 & 0.299 & . & 0.920 \\
\hline Var93 & 97.9630 & 175.131 & 0.542 & . & 0.918 \\
\hline Var94 & 98.1111 & 172.138 & 0.591 & . & 0.917 \\
\hline Var95 & 98.1667 & 176.330 & 0.463 & . & 0.918 \\
\hline Var101 & 98.0556 & 172.921 & 0.559 & . & 0.917 \\
\hline Var102 & 98.0926 & 174.765 & 0.467 & . & 0.918 \\
\hline Var104 & 98.2222 & 174.931 & 0.550 & . & 0.917 \\
\hline Var107 & 98.0370 & 173.810 & 0.552 & . & 0.917 \\
\hline Var108 & 97.9630 & 173.508 & 0.647 & . & 0.917 \\
\hline Var112 & 98.0370 & 178.112 & 0.323 & 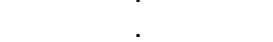 & 0.920 \\
\hline Var113 & 97.9815 & 174.698 & 0.516 & . & 0.918 \\
\hline Var116 & 98.1111 & 174.780 & 0.491 & . & 0.918 \\
\hline Var118 & 98.3704 & 183.483 & 0.021 & . & 0.922 \\
\hline
\end{tabular}

data set copied as such from excel or any document ii) Variable view in this the all the details (name, type, measure, width, etc.) for each variable is feed prior copying the data in the data view. Applying factor analysis: Factor analysis is a statistical technique, which is used to identify a relatively small number of underlying dimensions, or factors, which can be used to represent relationships among interrelated variables. It helps in the identification of underlying factors that might explain the dimensions associated with data variability (Badiru, 2002). Rummel (1990) have also argued that social scientists have been using factor analysis extensively for examining patterns of interrelationships, data reduction, instrument development, classification and description of data, data transformation, hypothesis testing, exploring relationships in new domains of interest and mapping construct space. The primary purpose of conducting factor analysis in the present study was to 
reduce the number of statements meant to measure the ICT competency. Factor analysis is done by through any many like principal component analysis, unweighted least squares, generalized least squares, maximum likelihood, principal axis factoring, alpha factoring and image factoring etc. The method of principal component analysis (PCA) was applied in the obtained data. PCA looks at the total variance among the variables, so the solution generated will include as many factors as there are variables. With the use of PCA and rotation method- 'Varimax with Kaiser Normalization' in the data, the variables were clustered under 25 major clusters (the correlation value was restricted to 0.60 and above). The clustered variables were keenly observed in order to sort them in terms of being relevant in judging competencies on use of ICTs in agricultural extension. A set of 45 variables (ICT-use competency) was finalized to be included in the tool, meant to assess the ICT competence of the extension personnel (Table 3 ). The $p$-value of the final set of statements for Bartlett's Test of Sphericity was also found to be significant $(p<0.001)$.

Assessing the validity and reliability of statements and finalization of competency tool: The face validity of all 118 statements was measured by asking the experts to rate the statements and most of the statements were stated as most relevant and relevant by majority of the people. The reliability of the statements was measured before and after applying the factor analysis. The finalized tool having a total of 45 statements had a Cronbach's alpha value of 0.920 (Table 4). A perusal of Table 5 also stated that the reliability of the each of the 45 statements varied was also high and the value varied from 0.916 to 0.923 .

\section{DISCUSSION}

A competency tool measures the level of individual proficiency across three major dimensions which are knowledge, skill, and attitude. The knowledge dimension refers to the user's basic understanding of technology and its value and benefits, skill dimension covers ability of information access/processing, evaluation, production, management, communication and use of internet network and attitude dimension indicates social as well as ethical consideration of the benefits and consequences of ICT(UNESCO, 2008). ICT competency aspects for the extension personnel have been discussed by many researchers (Thomas and Lasinde, 2013; Gangadharan, 2015; Umar, 2015) and were used in forming a set of 118 statements. The set of 118 statements sent to the respondents for judging relevancy with specific focus on knowledge and skill dimensions. As soon as the responses were obtained from the required number of respondents was obtained, the data was subjected to outlier analysis. The proper number of respondents for enhancing the power of the test is between 10 and 20 respondents (Hair et al., 2010). Outlier analysis was conducted in order to rule out any possibility of error that might influence the obtained responses as empirically documented by Huang et al., (2006). The obtained data set was supposed to help in developing a competency tool, therefore was subjected to PCA. After applying PCA, statements were exacted on the basis of correlation score of 0.60 and above, as this increased the possibility of including more competencies. The notion of how much value of correlation should be acceptable varies largely amongst research studies (Field, 2005; Roab et al., 2012, Wu et al., 2016). The face validity was adjudged as very relevant for most and relevant for some of the statements by the respondent. The overall reliability of the finalized tool (set of 45 statements) was very high i.e., Cronbach's alpha value was 0.920 , even the individual statements had very high reliability value varying from 0.916 to 0.923 . The obtained reliability estimates meet the minimal criterion value of 0.70 and above (Hair et al., 2010; Roab et al., 2012, Manna et al., 2016).

\section{Conclusion}

The present study made an attempt to develop 45 -statements based competency tool following a systematic procedure from data checking/ correction, outlier analysis, feeding data in SPSS, factor analysis and reliability analysis using SPSS software and MS Excel. The tool had high face validity and reliability and can serve well to measure ICT competence of the extension personnel in the field of agricultural extension. The tool will serve to provide empirical data on the ICT training gap i.e., the difference between existing and required ICT competencies of the extension personnel. Therefore, it will aid in determination of realistic ICT training needs for the extension personnel. The identified needs will aid in design and development of ICT training interventions, with specific focus on developing ICT competencies of extension personnel for the state. Its long term implication will be manifested in efforts of designing action-oriented ICT policy framework for agricultural extension of the organizations and the country as whole.

\section{ACKNOWLEDGEMENTS}

The author would like to acknowledge UGC for funding the above mentioned work of Ph.D. degree programme through NET-JRF Fellowship and the Department of Agricultural Communication, College of Agriculture, G.B. Pant University of Agriculture and Technology, Pantnagar for generating insight in context of the research problem. 


\section{REFERENCES}

1. Albert, C. O. (2014). Constraints to effective use of ICT among extension professionals and farmers in extension delivery in rivers state, Nigeria. Singaporean Journal of Business Economics, and Management Studies, 2(11): 136-142.

2. Badiru, A. B. (2002). An Integrative Study of Factors of Globalization and Industrial Development in Less Developed Regions of the Word, Research Proposal submitted to UT Global Studies Initiative, April, 2002.

3. Barnett, V. and Lewis, T. (1994). Outliers in Statistical Data. John Wiley \& Sons, New York.

4. Bell, M. (2015). Powering Behaviour Change for a Brighter Agricultural Future. MEAS Discussion Paper, University of California, Davis.

5. Chatterjee, J. and Prabhakar, T. V. (2009). On to Action- Building Digital Eco-system for Knowledge Diffusion in Rural India. Retrieved online from http:// www.cse.iitk.ac.in/users/tvp/papers/ vof_pasadena.pdf

6. Coll, C. (2004). Psychology of education and educational practices mediated by information and communication technologies. A constructivist look (Psicología de la educación y prácticas educativas mediadas porlas tecnologías de la informacióny la comunicación. Una mirada constructivista). SINÉCTI$C A, 25:$ 1-24.

7. CTA (2003). ICTs- Transforming Agricultural Extension? $6^{\text {th }}$ Consultative Expert, Wageningen, Netherlands, 14: 23-25. Available online form http:// ictupdate.cta.int/en/Feature-Articles/ICTstransforming-agricultural-extension

8. Federal Ministry of Education (2010). National policy on information and communication technologies (ICT) in education. Abuja: Federal Ministry of Education, Nigeria.

9. Field, A. P. (2005). Discovering Statistics using SPSS, $\left(2^{\text {nd }}\right.$ edition $)$. Sage Publication, London.

10.Gangadharan, C. (2015). Strategies for Capacity Building of Extension Personnel for Using Information and Communication Technologies. Unpublished M.Sc. Thesis, Department of Agricultural Extension, College of Horticulture, Vellanikkara, Thrissur - 680656, Kerala, India.

11.Glendenning, C. J., Babu, S. C. and Asenso-Okyere, K. (2010). Review of Agricultural Extension in India Are Farmers' Information Needs Being Met?. IFPRI Discussion Paper 01048, December 2010. Available online from www.ifpri.org/publication/reviewagricultural-extension-india

12.Grubbs, F. (1969). Procedures for detecting outlying observations in samples. Technometrics, 11(1): 1-21.

13.Hair, J. F., Black,W. C., Anderson, R. E., and Babin, B. J. (2010). Multivariate data analysis, ( $7^{\text {th }}$ edition). New Jersey: Prentice Hall.

14. Huang, H. Y., Lin, J. X., Chen, C. C. and Fan, M. H. (2006). Review of Outlier Detection. In: Application Research of Computers, pp. 8-13.

15.Kirschner, P. and Woperies, I. G. (2003). Pedagogic benchmarks for information and communication technology in teacher education. Technology, Pedagogy and Education, 12(1): 127-149.

16.Koyenikan, J. M. (2011). Extension workers' access to climate information and sources in Edo State Nigeria. Archives of Applied Science Research,3(4):11-20

17.Lawal -Adebowale, A. O. (2008). Information and
Communication Technology: Its Potentials for Enhanced Agricultural Extension Service and Rural Development. In Agbamu, J. U. (ed.), Perspectives in Agricultural Extension and Rural Development. Springfield Publishers Ltd., Owerri.

18.Lele, U., Pretty, J., Terry, E. and Trigo, E. (2010). Transforming Agricultural Research for Development. The Global Forum for Agricultural Research (GFAR) Report for the Global Conference on Agricultural Research (GCARD), 2010. Available online from www.fao.org/docs/eims/upload/282426/ GAT_Report_GCARD_2010_complete.pdf

19.Manna, R., Singh, A. and Shamra, P. (2016). Does Training Need Analysis Help to Minimize Competency Gap: An Investigation. Amity Journal of Training and Development, 1(1): 109-131.

20.Mishra, D. C. (1990). New Directions in Extension Training, Directorate of Extension, Department of Agriculture and Cooperation, Ministry of Agriculture, New Delhi.

21.Molina, T. V., Collazos, A. S., Angrino, S. O., Tamayo, A. M. C., González, J. A. M. and Vescance, J. D. C. (2016). ICT standards and competencies from the pedagogical dimension: A perspective from levels of ICT adoption in teachers' education practice. Pontificia Universidad Javeriana - Cali (Colombia). UNESCO-Santiago.

22.Mukherjee, A. and Maity, A. (2015). Public-private partnership for convergence of extension services in Indian agriculture. Current Science, 109(9): 15571563.

23.Munyua, H. (2008). Final report. ICTs and smallscale agriculture in Africa: a scoping study, Report prepared on behalf of the International Development Research Centre (IDRC). Available online from http:// ideas.repec.org/p/iim/iimawp/2005-11-04.html

24.NSAE. (2009). National Seminar on Agriculture Extension. 27-28 ${ }^{\text {th }}$ February, 2009, NAS Complex, PUSA, New Delhi. Retrived online from http:// www.syngentafoundation.org/db/1/657.pdf

25.Omotayo, O. M. (2005). ICT and Agricultural Extension. Emerging issues in transferring agricultural technology in developing countries. In: Adedoyin S.F. (ed), Agricultural Extension in Nigeria. Ilorin: Agricultural Extension Society of Nigeria.

26. Ratna, S. (2008). Mainstreaming ICT for faster and more inclusive growth and development in livestock sector: Digital inclusion for rural prosperity and grassroots development, presented as a theme paper at national conference on distance education to animal farmers with emphasis on Women self-help groups, held at Banaras Hindu University (BHU), on 1-3 February 2008.

27.Roab, I., Al-Oshaibat, H. and Lan, S. O. (2012). A Factor Analysis of Teacher Competency in Technology. New Horizons in Education, 60(1): 13-22.

28.Rummel, R. J. (1990). Applied Factor Analysis. Evanston, IL: Northwestern University Press.

29.Salomon, I., Cohen, G. and Nijkamp, P. (1999). ICT and urban public policy: does knowledge meet policy? Research Memorandum, 47. Available online from http://degree.ubvu.vu.nl/repec/vua/wpaper/ pdf/19990047.pdf.

30.Sanusi, M. A., Petu-lbikunle, A. M. and Mohelia, C. M. (2010). The influence of ICT on the dissemination of Agricultural Information among urban farmers in Northern Guinea Savannah Zone of Nigeria. African 
Kothari, D. and Kameswari, V.L.V. / J. Appl. \& Nat. Sci. 11(2): 352- 360 (2019)

Scientist, 11(2): 135-140.

31.The Minnesota Governor's Council on Developmental Disabilities. Competencies for Information and Communication Technology (ICT) Literacy. Available online from http://mn.gov/mnddc/asd-employment/6a -ict-competencies.html

32. Thomas, K. A. and Laseinde, A. A. (2013). Training Needs Assessment on the Use of Social Media among Extension Agents in Oyo State, Nigeria. Journal of Agricultural Informatics, 6(1): 100-111. doi:10.17700/jai.2015.6.1.144

33.Umar, S., Musa, M. W., Olayemi, Y. T. and Suleiman, R. (2015). Awareness and Use of Information and Communication Technologies among Extension Agents in Kaduna State of Nigeria. Journal of Agricultural Extension, 19(1): 66-76.

34.UNESCO. (2008). Strategy framework for promoting ICT literacy in the Asia-pacific region. Bangkok.Available online from http://unesdoc.unesco.org/ images/0016/001621/162157e.pdf.

35.Wu, X. V., Enskär, K., Pua, L. H., Heng, D. G. N. and Wang, W. (2016). Development and psychometric testing of Holistic Clinical Assessment Tool (HCAT) for undergraduate nursing students. BMC Medical Education,16: 1-9. https://doi.org/10.1186/s12909016-0768-0 